\title{
Introduction from the Guest Editor
}

As Confucius said to the hen-pheasant of the hill bridge, 時 哉時哉—the important thing is to get the timing right (Lun yu 論 語, Xiang dang 㰾黨).

Ho Peng Yoke is 80 in 2006. That celebratory proclamation is of course the reason why a collection of papers whose genesis took place in discussions during the closing weeks of 2001 was carefully scheduled for release five years later. As Guest Editor for this issue of EASTM, I claim all the credit for the ingenious procrastination that went into achieving this very fitting timing, which only the ill-conditioned would think of connecting with any other deadlines that have surged over my head during the last five years.

Ho Peng Yoke is an extraordinary man. He is certainly extraordinary in the depth and breadth of his learning, both humane and scientific, and in the variety of the roles in which he has made himself useful to the point of indispensability throughout a long working life. But above all that he is just an extraordinarily nice man. To understand why so many people who have met him think that way, you have only to turn to his recently published autobiography (Ho 2005), as well as looking at the personal note from Nathan Sivin that follows this introduction. No life spent amongst academics (a group rightly unrenowned for their-well, our-universal amiability and lack of quarrelsomeness) can be free of personal conflicts and the experience of lack of consideration for others. Most people find it more than a little interesting to read accounts of such incidents, especially where they involve other well-known figures showing the weaker side of their personalities. As a person intimately involved in academic life at the highest levels in at least half a dozen different countries and on three different continents, Ho Peng Yoke could have gathered plenty of such material. But this autobiography is devoid of complaints and paybacks. It is not just that he seems to have viewed the people and places he experienced in his own very varied life in an almost wholly positive light. So far as my own quite wide experience goes, the people who have known him all feel that way about him too.

My own personal debts are deep ones, and are closely linked to his contributions to developing our field in more general terms. It was Ho Peng Yoke who guided me towards raising the funds that enabled SOAS to transform my first (temporary) job into a permanent appointment. This enabled me to begin taking on research students, one of whom in turn now holds a permanent post in the University of London. This initiative therefore has had the effect of establishing two UK scholars in jobs in the history of Chinese science and medicine. Later his support was crucial in the much larger fund-raising effort that helped to endow the full-time salaried Directorship of the Needham Research Institute in Cambridge, which I now hold. Of course his own previous years of service in that post, undertaken at Joseph Needham's personal urging, had been non-stipendiary and had necessitated his taking early retirement from Griffiths University in Australia. Without his support it is by no means certain that the NRI could have made 
the transition to being a permanent institution with an active intellectual life after the passing of its great founder.

Members of the International Society for the History of East Asian Science Technology and Medicine will remember Ho Peng Yoke as a tireless contributor to the life of the society. He personally organised two of its conferences - the only person to do so - and played a key role in setting up and ensuring the success of our conference in Singapore.

Niceness and helpfulness to colleagues, rare as it is to find them so consistently held to, are not enough in themselves. Ho Peng Yoke is also a scholar whose work ranges through alchemy, astronomy, mathematics, and the complex of applied temporally structured cosmologies that we usually call 'divination.' Indeed we may say that it was his work that decisively drew the attention of Western scholars of Chinese science to the importance of this subject, an importance that had not been stressed in the Needham oeuvre. Apart from that, one of his greatest achievements is undoubtedly the volume on gunpowder and gunpowder weapons in Joseph Needham's Science and Civilisation in China series. But despite the fact that the entire first draft of this book came from his own hand, the then series editors were content merely to show him as a 'collaborator' of the main series author: all this he passes over with the wry amusement that is his usual reaction to life's ironies.

He has continued to publish at an age that one can only hope will eventually rival Needham's own long career. A book on alchemy and medicine is now in press, and was preceded only three years ago by a groundbreaking and exemplarily comprehensible study of numerological astral divination (Ho 2003). The knowledge that Ho Peng Yoke was just completing this latter book was the spur for a workshop on divination in his honour, held at the Needham Research Institute in December 2001. The papers presented in this special issue have grown out of some of the contributions offered by the scholars who gathered there.

Before beginning the issue proper, we have a personal contribution from $\mathrm{Na}-$ than Sivin, an eminent scholar from what is perhaps the earliest generation to have been influenced, helped and stimulated by contact with Ho Peng Yoke. As we can read there, such influence could have dramatic results, at least when the student was not aware of the way the mechanical properties of pyrex change with temperature ... We then move straight into a substantial study by Robin Yates, part of the fruits of the years of research he has devoted to completing the military sections of Science and Civilisation in China. Here he shows us just how important divination was in military practice as well as in the literature of the premodern military sciences in China. The workshop in 2001 was comparative and cross-regional, which gives us the opportunity to include a typically luminous contribution by Yano Michio in which he explores medicine and divination in India. The comparative spirit begun in India leads on into Chang Che-chia's fascinating study of examples of cross-cultural encounters between medicine and astrology in both modern and pre-modern China, centred on one sixteenth century text including material of Indian origin which the author struggled to fit into a 
Chinese frame of reference. Lisa Raphals uses the lens of comparison between ancient China and ancient Greece to study medical divinations from Baoshan and the records of Asclepian divination in the West. An entirely different type of divination is studied by Bernhard Führer, who introduces us to the ways in which written Chinese characters could be dissected as a means of foretelling events, or used as a means of encoding information that was not intended to be easily understood. Finally a substantial discussion by David Brown leads us back to the comparative perspective, giving invaluable insight into the changing methodology of a field whose increasing sophistication is a challenge to those of us interested in East Asian sky-lore - the study of the evolution of predictive astrology in ancient Mesopotamia.

Perhaps the most appropriate closing tribute to the scholar to whom this special issue is respectfully offered by all its contributors is to say that he is likely to be interested in every one of the very varied pages it contains.

Ho, Peng Yoke (2003). Chinese Mathematical Astrology: Reaching out to the Stars. London: Routledge (Needham Research Institute Series).

(2005). Reminiscence of a Roving Scholar: Science, Humanities, and Joseph Needham. New Jersey, London, Singapore: World Scientific Pub. Co.

Christopher Cullen

Nedham Research Institute and Darwin College

Cambridge 